\title{
Analisis Determinan Dana Pihak Ketiga Bank Umum Syariah di Indonesia
}

\author{
Ayif Fathurrahman $^{1 *)}$, Yuyun Setiawansi ${ }^{2)}$ \\ ${ }^{1,2}$ Prodi Ekonomi, Universitas Muhammadiyah Yogyakarta \\ *Email korespondensi: ayief_ospp@yahoo.com
}

\begin{abstract}
This study aims to analyze the effect of inflation, exchange rate, BI Rate and Return On Assets (ROA) on Third Party Funds of Sharia Commercial Banks in Indonesia. Data used in the study are Third Party Funds, Inflation, Exchange Rate, BI Rate and Return On Assets (ROA). In this study using multiple linear regression methods and test classic assumptions with the help of Stata application. The results showed that Inflation variable $(0,226)$ had a positive and not significant relationship to Third Part Funds of sharia commercial banks in Indonesia. BI Rate variable $(0,000)$ has a negative and significant relationship to Third Part Funds of sharia commercial banks in Indonesia. While the Exchange Rate $(0,000)$ and Return On Assets $(0,000)$ have a positive and significant relationship to Third Part Funds of sharia commercial banks in Indonesia.
\end{abstract}

Keywords: Third Part Funds, Inflation, Exchange Rate, BI Rate and Return On Assets (ROA)

Saran sitasi: Fathurrahman, A., \& Setiawansi, Y. (2021). Analisis Determinan Dana Pihak Ketiga Bank Umum Syariah di Indonesia. Jurnal Ilmiah Ekonomi Islam, 7(01), 154-163. doi:http://dx.doi.org/10.29040/jiei.v7i1.1608

DOI: http://dx.doi.org/10.29040/jiei.v7i1.1608

\section{PENDAHULUAN}

Perkembangan peran perbankan syariah di Indonesia tidak terlepas dari sistem perbankan di Indonesia secara umum. Melihat potensi bank syariah di Indonesia sangat besar mengingat sekitar $87 \%$ penduduknya muslim. Namun sayangnya penguasaan pasar atau market share bank syariah di industri perbankan nasional masih rendah dibandingkan dengan bank konvensional. Oleh karena itu, diperlukan usaha yang lebih baik untuk meningkatkan market share tersebut salah satunya dari segi kinerja keuangan. Indikator peningkatan kinerja dalam perbankan syariah adalah peningkatan aset yang diantaranya dapat dilihat melalui peningkatan pengumpulan Dana Pihak Ketiga.

Menurut Undang-Undang Nomor 10 Tahun 1998 tentang Perbankan pada pasal 1 ayat 5 memberikan pengertian simpanan pada bank adalah sebagai dana yang dipercayakan oleh masyarakat kepada bank berdasarkan perjanjian penyimpanan dana dalam bentuk giro, deposito, sertifikat deposito, tabungan dan atau bentuk lainnya. Sumber dana yang diperoleh pihak ketiga ini akan memberikan dampak pada kemampuan dalam memenuhi skala dan volume transaksi yang pada akhirnya akan dapat meningkatkan laba.

Modal terbesar dari bank adalah dana mayarakat. Masyarakat akan memilih untuk menabung atau menginvestasikan dananya tergantung pada pendapatan yang mereka miliki, kondisi ini juga akan mempengaruhi perkembangan Dana Pihak Ketiga (DPK). Kondisi ekonomi makro juga dapat mempengaruhi Dana Pihak Ketiga (DPK) pada perbankan syariah karena akan mempengaruhi individu, kelompok, maupun perusahaan untuk bertransaksi. Ketika kondisi pendapatan nasional membaik maka meningkatkan pendapatan masyarakat yang akhirnya akan meningkatkan Dana Pihak Ketiga (DPK) pada bank syariah. 
Jurnal Ilmiah Ekonomi Islam, 7(01), 2021, 155

\section{Grafik 1}

\section{DPK Bank Umum Syariah di Indonesia Periode Juli 2015 - Juli 2019}

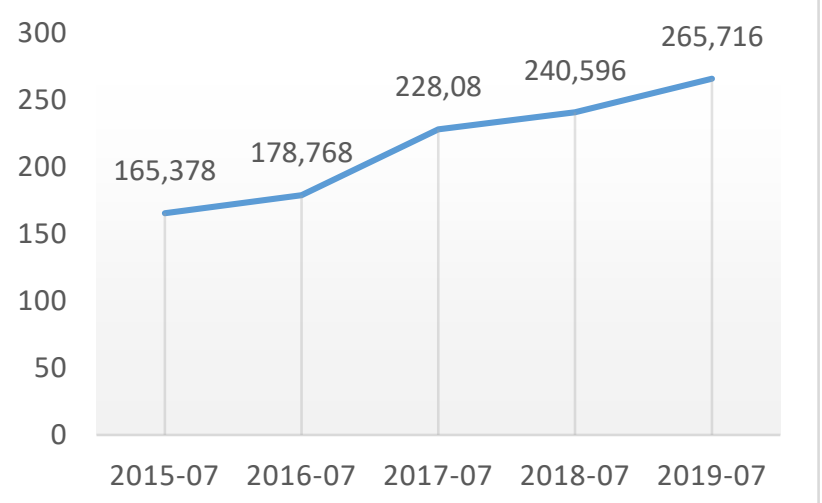

Sumber: SPS OJK (diolah)

Berdasarkan grafik 1 diatas, dapat diketahui bahwa perkembangan dana pihak ketiga bank umum syariah dari Juli 2015 sampai dengan Juli 2019 terus mengalami peningkatan. Dimulai dari Juli 2015 dengan total dana pihak ketiga sebesar 165.378 miliar. Lonjakan tertinggi terjadi pada Juli 2019 yaitu sebesar 265.716 miliar dengan kenaikan sebesar 178.768 miliar di bulan Juli 2016, 228.080 miliar di bulan Juli 2017 serta 240.596 miliar dibulan Juli 2018. Volume tinggi rendahnya dana pihak ketiga dapat dijadikan cara mengukur kualitas suatu bank. Semakin tinggi volume dana pihak ketiga suatu bank maka mengidentifikasikan bahwa semakin berkualitasnya bank tersebut serta menandakan bahwa masyarakat semakin percaya kepada bank tersebut. Sebaliknya, jika volume dana pihak ketiga menurun maka dapat dikatakan bahwa bank tersebut memiliki kualitas yang kurang baik sehingga masyarakat kurang percaya terhadap bank tersebut (Dyatama dan Yuliadi, 2015).

Selain kondisi tersebut, kondisi ekonomi makro juga berpengaruh terhadap Dana Pihak Ketiga (DPK) pada bank syariah (Sangadah, 2013; Prasetyoningrum, 2015; Rivai, 2006). Faktor makro yang pertama adalah inflasi, dimana inflasi merupakan salah satu variabel ekonomi makro yang sangat berpengaruh terhadap kondisi perekonomian di Indonesia. Tingginya tingkat inflasi yang terjadi di suatu negara akan menyebabkan hilangnya kepercayaan masyarakat dan akan menurunkan kekayaan dalam bentuk uang, sehingga masyarakat cenderung akan menyimpan aktiva mereka dalam bentuk lain seperti emas dan property yang bisa bertahan nilainya ketika terjadi inflasi. Semakin tinggi inflasi maka kegiatan penghimpunan dana pada bank akan berpengaruh.
Maka perlu adanya perhatian khusus untuk menghadapi inflasi sehingga kondisi perbankan dapat stabil.

\section{Grafik 2.}

Inflasi di Indonesia Periode Juli 2015 - Juli 2019

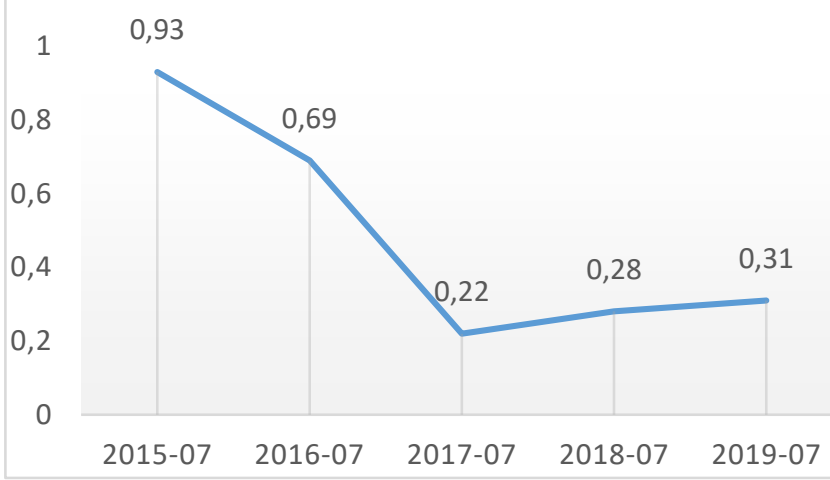

Sumber: Badan Pusat Statistik (diolah)

Berdasarkan grafik 2 dapat diketahui bahwa perkembangan inflasi pada Juli 2015 merupakan inflasi tertinggi yang terjadi di Indonesia yaitu sebesar 0,93 persen. Hal ini diakibatkan karena pada Juli 2015, inflasi terjadi karena adanya kenaikan harga di seluruh indeks kelompok pengeluaran.

Faktor kedua ekonomi makro adalah nilai tukar atau kurs. Kurs dapat digunakan sebagai salah satu indicator untuk mengukur kestabilan perekonomian. Karena kurs mata uang suatu negara ini sering mengalami perubahan kenaikan maupun penurunan. Akibatnya, pemerintah harus memberikan perhatian lebih terhadap nilai tukar agar tetap stabil. Apabila kurs mata uang asing (dollar AS) rendah, maka hargaharga barang dalam negeri akan stabil yang berakibat baik pada perekonomian dalam negeri. Hal tersebut juga akan berdampak terhadap simpanan masyarakat pada bank syariah juga akan meningkat. (Rivai, 2006).

BI Rate adalah faktor ekonomi makro yang mempunyai peranan penting dalam perekonomian. Suku bunga mencerminkan biaya yang harus dikeluarkan untuk meminjam sejumlah dana serta pendapatan yang diperoleh karena meminjam dana tersebut. Sistem perbankan di Indonesia secara umum telah menggunakan tingkat suku bunga. Hal tersebut ditawarkan bank konvensional untuk menarik nasabah dalam menyimpan uangnya. Berbeda dengan bank konvensional, bank syariah menolak adanya sistem bunga pada kegiatan operasionalnya. Meskipun demikian, suku bunga secara hubungan teoritis akan menjadi pertimbangan Bank syariah menentukan kebijakan tingkat bagi hasil dan margin murabahah. 


\section{Grafik 3}

BI Rate di Indonesia Periode Juli 2015 - Juli 2019

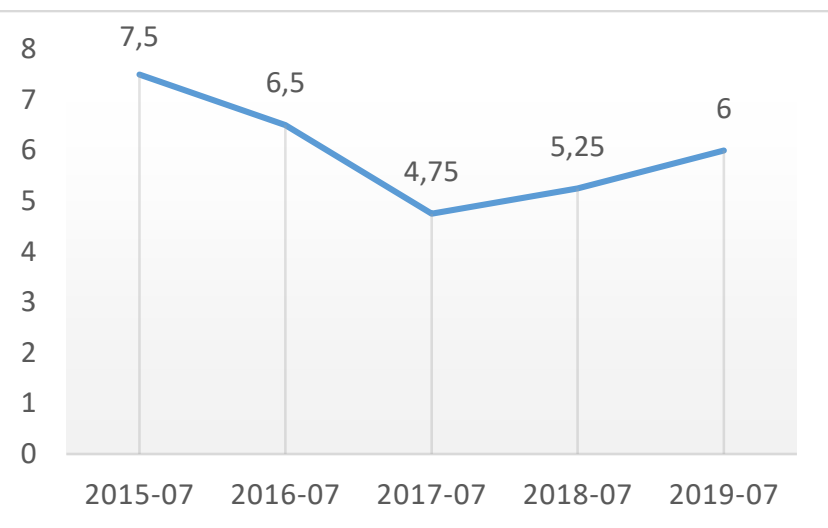

Sumber: Bank Indonesia (diolah)

Berdasarkan grafik 3 dapat diketahui bahwa perkembangan suku bunga Juli 2015 merupakan suku bunga tertinggi yang terjadi di Indonesia yaitu sebesar 7,5 persen/

Adapun beberapa penelitian yang telah dilakukan seperti Wibowo dan Suhendra (2008) yang fokus pada Pengaruh Kurs, Inflasi, dan Tingkat SB terhadap DPK pada Bank Devisa di Indonesia. Hal ini juga pernah diperkuat oleh Khoirunnisa dan Soelistyo (2010) yang fokus pada pendapatan nasional dan tingkat suku bunga terhadap Dana Pihak Ketiga pada Bank Umum di Indonesia. Sopiana (2012) juga menganalisis mengenai pengaruh suku bunga SBI dan inflasi terhadap penghimpunan Dana Pihak Ketiga (DPK) perbankan di Indonesia. Kefi dan Sutono (2013) menganalisis mengenai pengaruh faktor makro ekonomi terdahap Dana Pihak Ketiga Bank Umum di Indonesia. Dan penelitian yang dilakukan oleh Saekhu (2017) menganalisis mengenai dampak indicator makroekonomi terhadap Dana Pihak Ketiga Perbankan Syariah.

Akan tetapi umumnya penelitian tersebut mengangkat secara parsial variabel makroekonomi sebagai variabel penelitian. Penelitian ini mencoba untuk mengissi gap penelitian terkait dana pihak ketiga (DPK) dengan beberapa variabel makroekonomi dan varibel kinerja keuangan.

Tujuan penelitian ini untuk menjelaskan pengaruh inflasi, kurs, BI rate dan return on asset (ROA) terhadap penghimpunan Dana Pihak Ketiga pada Bank Umum Syariah di Indonesia periode 20152019.

\section{METODE PENELITIAN}

Objek yang digunakan dalam penelitian ini yaitu Bank Umum Syariah di Indonesia. Penelitian ini menggunakan pendekatan kuantitatif dengan pengambilan data sekunder berdasarkan pada data runtut waktu (time series) dari bulan Januari 2015 sampai dengan Juli 2019. Untuk dapat mengetahui apakah model regresi yang digunakan telah memenuhi syarat atau kriteria, maka akan dilakukan uji normalitas, uji auotokerelasi, uji multikolinearitas, dan uji heteroskedastisitas terlebih dahulu.

Teknik analisis yang digunakan dalam penelitian ini yaitu teknik analisis berganda yang mencakup uji $\mathrm{F}$, uji t dan Uji koefisien determinasi $\left(\mathrm{R}^{2}\right)$, untuk mendapatkan gambaran yang menyeluruh mengenai hubungan antara variabel dependen dengan variabel independen yang dirumuskan sebagai berikut:

$$
\mathrm{Y}=\mathrm{a}+\beta_{1} \mathrm{X}_{1}+\beta_{2} \mathrm{X}_{2}+\beta_{3} \mathrm{X}_{3}+\beta_{4} \mathrm{X}_{4}+\mathrm{e}_{\mathrm{i}}
$$

Dimana:

$$
\begin{array}{ll}
\mathrm{Y} & =\text { Dana Pihak Ketiga (DPK) } \\
\mathrm{a} & =\text { Konstanta } \\
\mathrm{X}_{1} & =\text { Inflasi } \\
\mathrm{X}_{2} & =\text { Kurs } \\
\mathrm{X}_{3} & =\text { BI Rate } \\
\mathrm{X}_{4} & =\text { Return On Assets (ROA) } \\
\mathrm{e}_{\mathrm{i} .} & =\text { Residual }
\end{array}
$$

\section{HASIL DAN PEMBAHASAN}

\subsection{Hasil Penelitian}

\section{a. Uji Asumsi Klasik}

Untuk memastikan bahwa model yang diperoleh merupakan model yang tepat, maka sebelumnya akan dilakukan uji asumsi klasik terlebih dahulu, yang terdiri antara lain:

\section{1) Uji Normalitas}

Untuk mengetahui variabel berdistribusi normal atau tidak, maka dalam penelitian ini menggunakan Skewness/Kurtosis test, sehingga diperoleh dari pengujian normalitas ini sebagai berikut:

Tabel 1. Hasil Uji Normalitas

\begin{tabular}{|c|c|c|}
\hline \multicolumn{3}{|c|}{ Skewness/Kurtosis test for Normality } \\
\hline Pr (Skewness) & $\operatorname{Pr}$ (Kurtosis) & Prob > chi2 \\
\hline 0,3389 & 0,9852 & 0,6227 \\
\hline
\end{tabular}

Berdasarkan hasil pengujian normalitas diatas, dapat disimpulkan bahwa variabel berdistribusi normal. Hal ini dapat dilihat dari nilai Pr (Skewness) sebesar 0,3389 dan Pr (Kurtosis) sebesar 0,9852 dengan nilai probabilitas sebesar 0,6227. Apabila dibandingkan dengan nilai signifikansi, 0,6227 lebih besar dibandingkan $0,05(0,6227>0,05)$, sehingga 
dapat disimpulkan bahwa model tersebut berdasarkan uji Skewness Kurtosis, residualnya dinyatakan berdistribusi normal.

\section{2) Uji Autokorelasi}

Untuk mengetahui ada atau tidaknya autokorelasi dalam penelitian ini menggunakan Breusch-Godfrey Lagrange Multiplier (LM) Test, sehingga diperoleh dari pengujian autokorelasi ini sebagai berikut:

\section{Tabel 2. Hasil Uji Autokorelasi}

\begin{tabular}{|c|}
\hline $\begin{array}{c}\text { Breusch-Godfrey LM test for } \\
\text { autocorrelation }\end{array}$ \\
\hline Prob > chi 2 \\
\hline 0.1285 \\
\hline
\end{tabular}

Dari hasil pengujian autokorelasi, dapat dilihat bahwa nilai probabilitasnya sebesar 0.1285 . Dengan kata lain nilai probabilitas lebih besar dari 0,05 , sehingga dapat dikatakan bahwa model tersebut berdasarkan Breusch-Godfrey LM test tidak memiliki masalah autokorelasi.

\section{3) Uji Heterokedastisitas}

Dalam penelitian ini uji heterokedastisitas yang digunakan yaitu uji Breusch-Pagan / Cook-Weisberg, sehingga pengujian ini akan menghasilkan nilai chi2 dan probabilitas chi2. Adapun hasil uji heterokedastisitas ini yaitu sebagai berikut:

Tabel 3. Hasil Uji Heterokedastisitas

\begin{tabular}{|c|c|}
\hline \multicolumn{2}{|c|}{$\begin{array}{c}\text { Breusch-Pagan / Cook-Weisberg for } \\
\text { Heteroskedasticity }\end{array}$} \\
\hline Chi2 (1) & Prob > Chi2 \\
\hline 2,09 & 0.1485 \\
\hline
\end{tabular}

Dari hasil pengujian heteroskedastisitas, dapat dilihat bahwa nilai chi2 (1) yaitu sebesar 2,09 dengan probabilitas sebesar 0,1485 . Dengan kata lain nilai probabilitas lebih besar dari $0,05(0,1485>0,05)$, sehingga data penelitian dapat digunakan karena model tersebut terbebas dari heteroskedastisitas.

\section{4) Uji Multikolinearitas}

Pendekatan multikolinearitas dapat dilihat melalui Variance Inflation Factors (VIF). Untuk melihat terdapat multikolinearitas atau tidak, maka dapat dilihat melalui Variance Inflation Factors (VIF).

Tabel 4. Hasil Uji Multikolinearitas

\begin{tabular}{|c|c|c|}
\hline Variabel & VIF & 1/VIF \\
\hline Inflasi & 1.01 & 0.988805 \\
\hline BI Rate & 1.12 & 0.896686 \\
\hline ROA & 1.61 & 0.620502 \\
\hline Kurs & 1.48 & 0.677650 \\
\hline Mean VIF & 1.30 \\
\hline
\end{tabular}

Apabila nilai VIF $<10$ dan $1 / \mathrm{VIF}>0,1$, maka dapat dikatakan bahwa model terbebas dari gejala multikolinearitas. Dari hasil pengujian diatas, dapat dilihat bahwa Inflasi < 10 (1.01), BI Rate < 10 (1.12), ROA $<10$ (1.61), dan Kurs < 10 (1.48), sehingga dapat disimpulkan bahwa model terbebas dari gejala multikolinearitas, karena nilai VIF $<10$.

\section{b. Uji Analisis Linear Berganda}

Adapun tabel dibawah ini menunjukan hasil pengujian linear berganda dengan menggunakan stata sebaga berikut:

Tabel 5. Hasil Uji Analisis Regresi Linear

\section{Berganda}

\begin{tabular}{|l|c|c|c|c|}
\hline \multicolumn{1}{|c|}{ DPK } & Koefisien & $\begin{array}{c}\text { Standar } \\
\text { Error }\end{array}$ & $\mathrm{T}$ & $\mathrm{P}>|\mathrm{t}|$ \\
\hline Inflasi & 6817.418 & 5565.274 & 1.22 & 0.226 \\
\hline Kurs & 18.19466 & 3.877641 & 4.69 & 0.000 \\
\hline BI Rate & -14888.7 & 1544.494 & -9.64 & 0.000 \\
\hline ROA & 47018.57 & 5978.112 & 7.87 & 0.000 \\
\hline $\mathrm{C}$ & 3372.26 & 49968.25 & 0.07 & 0.946 \\
\hline Number of obs $=55$ \\
\hline F (4, 50) $=92.01$ \\
\hline Prob $>$ F $=0.0000$ \\
\hline R-squared $=0.8804$ \\
\hline Adj R-squared = 0.8708 \\
Model regresi yang diperoleh dari hasil penelitian \\
diatas dapat ditulis dalam bentuk persamaan: \\
Y = 3372.26 + 6817.418Inflasi + 18.19466Kurs - \\
14888.7BIRate + 47018.57ROA + e \\
Persamaan model regresi tersebut dapat
\end{tabular}
dijelaskan sebagai berikut:

1) Apabila Inflasi, Kurs, BI Rate dan ROA diasumsikan cateris paribus (variabel independen dianggap konstan atau nol), maka nilai Dana Pihak Ketiga yang ada di Bank Umum Syariah yaitu sebesar 3.372 miliar.

2) Variabel Inflasi diperoleh koefisien sebesar 6817.418 dengan arah koefisien positif. Hal ini berarti apabila Inflasi meningkat sebesar 1 persen, maka Dana Pihak Ketiga Bank Umum Syariah akan meningkat sebesar 68,17 miliar dengan asumsi variabel lain konstan.

3) Variabel Kurs diperoleh koefisien sebesar 18.19466 dengan arah koefisien positif. Hal ini berarti apabila kurs meningkat sebesar 1 rupiah, maka Dana Pihak Ketiga Bank Umum Syariah akan meningkat sebesar 18 miliar dengan asumsi variabel lain konstan. 


\section{Jurnal Ilmiah Ekonomi Islam, 7(01), 2021, 158}

4) Variabel BI Rate diperoleh koefien sebesar 14888.7 dengan arah koefisien negatif. Hal ini berarti apabila BI Rate naik sebesar 1 persen, maka Dana Pihak Ketiga Bank Umum Syariah juga akan turun sebesar 148.887 miliar dengan asumsi variabel lain konstan.

5) Variabel Return On Asset (ROA) diperoleh koefisien sebesar 47018.57 dengan arah koefisien positif. Hal ini berarti apabila ROA naik 1 persen, maka Dana Pihak Ketiga Bank Umum Syariah juga akan meningkat sebesar 470,18 niliar dengan asumsi variabel lain konstan.

\section{c. Uji T}

Uji $\mathrm{T}$ digunakan untuk mengetahui apakah masing-masing variabel inflasi, kurs, BI rate, dan Return On Assets (ROA) terhadap variabel dependen saling berpengaruh atau tidak. Berdasarkan hasil uji $\mathrm{t}$ dapat dilihat pada tabel di atas maka dapat dijelaskan sebagai berikut:

1) Pengaruh Inflasi terhadap Dana Pihak Ketiga

Berdasarkan hasil pengujian secara parsial inflasi terhadap dana pihak ketiga, diperoleh nilai probabilitas sebesar 0,226. Karena nilai probabilitas 0,226 lebih besar dari 0,05, maka dapat dinyatakan bahwa inflasi secara parsial tidak berpengaruh signifikan terhadap dana pihak ketiga bank umum syariah.

2) Pengaruh Kurs terhadap Dana Pihak Ketiga

Berdasarkan hasil pengujian secara parsial kurs terhadap dana pihak ketiga, diperoleh nilai probabilitas sebesar 0,000 . Karena nilai probabilitas 0,000 lebih kecil dari 0,05, maka dapat dinyatakan bahwa kurs secara parsial berpengaruh signifikan tehadap dana pihak ketiga bank umum syariah.

3) Pengaruh BI Rate terhadap Dana Pihak Ketiga

Berdasarkan hasil pengujian secara parsial BI Rate terhadap dana pihak ketiga, diperoleh nilai probabilitas sebesar 0,000 . Karena nilai probabilitas 0,000 lebih kecil dari 0,05, maka dapat dinyatakan bahwa BI Rate secara parsial berpengaruh signifikan terhadap dana pihak ketiga bank umum syariah.

4) Pengaruh Return On Assets (ROA) terhadap Dana Pihak Ketiga

Berdasarkan hasil pengujian secara parsial Return On Assets (ROA) terhadap dana pihak ketiga, diperoleh nilai probabilitas sebesar 0,000. Karena nilai probabilitas 0,000 lebih kecil dari
0,05, maka dapat dinyatakan bahwa Return On Assets (ROA) secara parsial berpengaruh signifikan terhadap dana pihak ketiga bank umum syariah.

\section{d. Uji F}

Dari hasil uji regresi berganda diperoleh F-test sebesar 0,0000. Karena nilai probabilitas F-test lebih kecil dari 0,05, maka $\mathrm{H} 0$ ditolak dan $\mathrm{H} 1$ diterima, sehingga dapat disimpulkan bahwa Inflasi, Kurs, BI Rate dan ROA secara bersama-sama memiliki pengaruh signifikan terhadap DPK Bank Umum Syariah.

\section{e. Uji Adjusted R-squared}

Koefisien determinasi menilai kemampuan variabel-variabel independen dalam menjelaskan variabel dependen. Berdasarkan tabel diatas dapat dilihat bahwa nilai Adj R-squared yaitu sebesar 0,8708. Hal ini berarti 87,08\% Dana Pihak Ketiga Bank Umum Syariah dapat dijelaskan oleh variabel Return On Asset (ROA), Inflasi, Kurs, dan BI Rate, sedangkan $12,92 \%$ lainnya dijelaskan oleh variabel lain yang tidak termasuk dalam penelitian ini. Adapun angka koefisien determinasi yaitu sebesar 0,8708 yang menandakan bahwa hubungan antara variabel dependen dan variabel independen cukup kuat karena memiliki nilai lebih dari $0,5(0,8708>0,5)$.

\subsection{Pembahasan}

Dari hasil pengujian diatas, maka dapat di interpretasikan dalam penelitian ini yaitu sebagai berikut:

a. Pengaruh Inflasi Terhadap Dana Pihak Ketiga Bank Umum Syariah

Inflasi diartikan sebagai suatu kecenderungan terjadinya kenaikan harga-harga umum secara terus menerus. Selain itu inflasi juga merupakan salah satu penyakit makro yang pengaruhnya sangat besar terhadap kestabilan jalannya perekonomian sehingga selalu menjadi perhatian pengambil kebijakan ekonomi (Pracoyo, 2004). Dalam perbankan, khususnya dalam kegiatan penghimpunan dana, naik turunnya inflasi akan mempengaruhi jumlah dana yang dihimpun oleh masyarakat. Karena dampak buruk dari inflasi bagi sektor perbankan yaitu pemilik dana atau nasabah akan mengalihkan uang yang dimilikinya untuk tujuan spekulasi. 


\section{Jurnal Ilmiah Ekonomi Islam, 7(01), 2021, 159}

Berdasarkan hasil penelitian diperoleh bahwa Inflasi mempunyai pengaruh yang tidak signifikan terhadap DPK Bank Umum Syariah dengan arah koefisien positif. Hal ini ditunjukkan dengan koefisien sebesar 6817.418 dengan tingkat signifikan sebesar 0,226. Karena tingkat signifikan lebih besar dari 0,05 maka secara parsial inflasi tidak berpengaruh secara signifikan dan positif terhadap Dana Pihak Ketiga.

Hasil penelitian ini menunjukkan bahwa setiap kenaikan inflasi maka akan meningkatkan Dana Pihak Ketiga Bank Umum Syariah di Indonesia. Hal ini sesuai dengan penelitian yang dilakukan oleh Saekhu yang menyatakan bahwa inflasi secara parsial tidak memiliki pengaruh yang signifikan terhadap Dana Pihak Ketiga Bank Umum Syariah. Meskipun inflasi mengakibatkan daya beli masyarakat menurun, namun masyarakat masih bisa memenuhi kebutuhannya tanpa harus menarik dana simpanannya yang ada di bank untuk keperluan konsumsi. Dimana dana yang diperoleh berasal dari kekayaan yang dimiliki, seperti halnya emas, asset, dan lain sebagainya, apabila masyarakat membutuhkan dana saat terjadinya inflasi untuk memenuhi kebutuhannya mereka tidak mengambil uang yang ditabung di bank syariah melainkan menjual asset yang dimiliki. Sehingga, tinggi rendahnya inflasi pada periode penelitian tidak berpengaruh signifikan terhadap jumlah Dana Pihak Ketiga Bank Umum Syariah di Indonesia.

Inflasi tidak berpengaruh signifikan terhadap Dana Pihak Ketiga. Hal ini menunjukkan bahwa meskipun inflasi mengalami kenaikan, namun keuntungan yang diperoleh bank syariah tidak mengalami penurunan yang signifikan. Pada dasarnya inflasi yang tinggi mencerminkan kenaikan barangbarang yang menjadikan nilai peredaran uang dapat berkurang akibat harga yang meningkat. Namun demikian dampak adanya inflasi nampaknya belum signifikan pada taraf 5\%, sehingga hal ini menunjukkan bahwa adanya inflasi tidak banyak mengurangi deposito maupun tabungan pada Bank Umum Syariah. hasil ini mengisyaratkan bahwa ada sedikit daya tahan Bank Umum Syariah terhadap adanya inflasi di Indonesia. Penelitian ini juga didukung oleh Kefi dan Sutono (2012) menyatakan bahwa inflasi memiliki pengaruh yang tidak signifikan terhadap dana pihak ketiga.

b. Pengaruh Kurs Terhadap DPK Bank Umum Syariah

Dari hasil penelitian diperoleh bahwa Kurs mempunyai pengaruh yang signifikan terhadap DPK Bank Umum Syariah dengan arah koefisien positif. Hal ini ditunjukkan dengan koefisien sebesar 18.19466 dengan tingkat signifikan 0,000 . Karena tingkat signifikan lebih kecil dari 0,05 maka secara parsial kurs berpengaruh secara signifikan dan positif terhadap Dana Pihak Ketiga. Ini berarti apabila rupiah mengalami depresiasi terhadap Dollar Amerika Serikat, maka akan menyebabkan pelarian modal (capital outflow) masyarakat keluar negeri karena return investasi di Indonesia lebih rendah. Sehingga perusahaan cenderung akan menarik dana likuid dengan return rendah agar permasalahan mengenai permodalan dapat teratasi.

Ketika permintaan nilai tukar terhadap Dollar AS naik, maka mengakibatkan permintaan uang domestik juga akan mengalami penurunan. Berdasarkan hal ini, perubahan nilai tukar rupiah terhadap Dollar AS memiliki pengaruh terhadap pertumbuhan Dana Pihak Ketika (DPK) diperbankan syariah. Nilai tukar valas akan menentukan imbal hasil investasi riil. Mata uang yang mengalami penurunan, maka akan menyebabkan daya beli dari pendapatan dan keuntungan modal yang dihasilkan dari jenis investasi apapun menjadi berkurang. Penurunan investasi ini akan mempengaruhi kegiatan operasional bank syariah. sehingga setiap perubahan nilai tukar akan mempengaruhi pendapatan dan profit bank syariah.

Melihat nilai positif dan signifikan nilai tukar terhadap dana pihak ketiga menunjukkan pada saat nilai dollar apresiasi maka akan meningkatkan dana pihak ketiga dibank syariah. Hal ini bisa terjadi karena masyarakat lebih memilih menyimpan uangnya di bank syariah saat harga dollar naik ketimbang membelanjakannya, karena harga terutama yang diekspor mengalami kenaikan harga. Artinya meskipun kurs relative fluktuatif, para nasabah tetap akan menabung atau menitipkan dananya di bank syariah, hal ini berlaku apabila nilai tukar 
apresiasi maka akan terjadi kenaikan ekspor dan harga menjadi stabil sehingga akan berpengaruh terhadap penghimpunan dana pihak ketiga mengalami peningkatan, diantaranya melalui deposito mudharabah, tabungan mudharabah, serta giro wadiah. Hal ini menunjukkan bahwa tingkat kepercayaan masyarakat yang cukup besar dalam hal menabung atau menitipkan uangnya kepada bank syariah walaupun kurs rupiah terhadap dollar mengalami kenaikan.

Hal ini juga didukung oleh penelitian yang dilakukan oleh Saekhu (2017) yang menyatakan bahwa kurs/nilai tukar memiliki pengaruh positif terhadap DPK, yang berarti setiap kenaikan kurs akan meningkatkan Dana Pihak Ketiga Perbankan Syariah. Apabila kurs naik, maka barang produksi atau jasa yang dihasilkan akan menjadi mahal ketika dihitung dengan mata uang asing. Akibatnya permintaan terhadap barang atau jasa diharapkan akan mengalami penurunan dan tidak menutup kemungkinan akan adanya penggunaan substitusi yang akhirnya akan menekan permintaan. Permintaan yang menurun juga akan diimbangi oleh penurunan pasokan yang dilakukan oleh produsen, sehingga masyarakat yang sebagai penerima balas jasa faktor produksi dan perusahaan sebagai produsen akan mengalami penurunan pendapatan. Hal ini mengakibatkan bank akan mengalami kesulitan dalam melakukan penghimpunan dana pihak ketiga, karena dana yang tersedia untuk diinvestasikan akan berkurang. Sedangkan dalam kondisi kurs turun, maka barang atau jasa yang dihasilkan relative lebih murah apabila dihitung dengan mata uang asing. Akibatnya permintaan terhadap barang atau jasa diharapkan akan mengalami kenaikan. Permintaan yang naik juga dapat meningkatkan pasokan sehingga akan tercipta keseimbangan baru. Hal ini akan mengakibatkan pertumbuhan ekonomi melalui dana yang diinvestasikan mengalami peningkatan. Akibatnya bank akan lebih mudah dalam melakukan penghimpunan dana pihak ketiga.

c. Pengaruh BI Rate Terhadap DPK Bank Umum Syariah

Dari hasil penelitian diperoleh bahwa BI Rate mempunyai pengaruh yang signifikan terhadap DPK Bank Umum Syariah dengan arah koefisien negatif. Hal ini ditunjukkan dengan koefisien sebesar -14888.7 dengan tingkat signifikan 0,000. Karena tingkat signifikan lebih kecil dari 0,05 maka secara parsial BI Rate berpengaruh secara signifikan dan negative terhadap Dana Pihak Ketiga. Hal ini berarti setiap kenaikan pada BI Rate akan menurunkan Dana Pihak Ketiga Perbankan Syariah.

Apabila BI Rate mengalami kenaikan, maka Bank Syariah juga harus menaikkan bagi hasil untuk nasabah agar mengimbangi suku bunga pada bank konvensional. Kondisi seperti ini dapat dijadikan sebagai pilihan investasi yang menarik pada simpanan Bank Syariah, sehingga dapat menaikkan dana pihak ketiga. Untuk menginterpretasikan hasil uji statistik pada penelitian ini, bertujuan untuk melakukan suatu strategi dalam menghimpun dana pihak ketiga agar terhindar dari akibat yang ditimbulkan oleh suku bunga yang meningkat pada bank konvensional. Sedangkan apabila BI Rate turun, maka penyimpanan dana di Bank Syariah juga akan melihat suku bunga pada bank konvensional sebagai pembanding untuk mengimbangi bank konvensional menaikkan suku bunga. Namun hal ini berlaku apabila terjadi kenaikan suku bunga akan berdampak terhadap investasi yang diberikan masyarakat ke bank syariah dalam bentuk simpanan. Hal ini dikarenakan tingginya suku bunga mengakibatkan keuntungan yang diberikan bank konvensional kepada nasabah cukup tinggi, sehingga membuat sistem bagi hasil bank syariah jauh dari bunga yang diberikan bank konvensional kepada nasabah.

Apabila perubahan yang dirasakan nasabah cukup signifikan, maka kondisi ini akan menjadikan simpanan bank untuk investasi kurang menarik, sehingga DPK Bank Syariah akan mengalami penurunan. Melihat hal tersebut, maka yang harus dilakukan oleh Bank Syariah ialah menurunkan bagi hasil untuk nasabah sebagai langkah untuk memperoleh keuntungan yang lebih besar.

Hal diatas berkaitan dengan perilaku nasabah dalam menentukan mana akses keuangan yang akan digunakan. Menurut Shiffman dan Kanuk (2000), yang diperhatikan konsumen atau nasabah dalam membeli, memanfaatkan, mengevaluasi, serta mengabaikan produk atau jasa yang diharapkan 


\section{Jurnal Ilmiah Ekonomi Islam, 7(01), 2021, 161}

dapat memuaskan kebutuhannya dengan cara mengkonsumsi produk dan jasa yang ditawarkan. Selama hal tersebut memberikan keuntungan, maka akan dipilih oleh masyarakat. Sehingga hal ini berkaitan dengan tujuan masyarakat untuk menempatkan dananya untuk diinvestasikan atau disimpan yang kapan saja bisa diambil. Ketika masyarakat ingin menginvestasikan dananya, maka tingkat return yang tinggi akan menjadi sebuah pilihan.

Apabila melihat kondisi Dana Pihak Ketiga bank syariah pada bulan September 2017, ada suatu hal yang menarik dari komposisi Dana Pihak Ketiga. Secara prpsentase, masyarakat yang bertujuan menempatkan dananya agar memperoleh keuntungan lewat deposito menempati urutan pertama yaitu sebesar 59,61\%, kemudian tabungan sebesar $28,40 \%$ dan giro sebesar $11,99 \%$. Hal ini berarti motif utama masyarakat dalam menempatkan dananya di bank syariah adalah untuk investasi yakni tercermin dari deposito yang menempati urutan pertama Dana Pihak Ketiga. Sehingga wajar apabila BI Rate merupakan acuan dari perbankan konvensional untuk menentukan imbalan bagi hasil simpanan atau funding akan mempengaruhi nasabah yang akan melakukan investasi karena memperlihatkan angka yang menjanjikan.

Dari penjelasan diatas, maka hasil dari penelitian ini adalah BI Rate mempunyai pengaruh signifikan terhadap dana pihak ketiga bank syariah di Indonesia dengan arah negatif. Hal ini berarti semakin besar BI Rate maka akan mengurangi jumlah dana pihak ketiga yang disimpan oleh bank syariah, begitu juga sebaliknya semakin kecil BI Rate maka dana pihak ketiga bank syariah yang disimpan semakin bertambah.

Penelitian ini juga didukung oleh penelitian yang dilakukan oleh Prasetyoningrum (2015) yang menyatakan bahwa BI Rate memiliki pengaruh yang signifikan dengan arah koefisien negative terhadap Dana Pihak Ketiga.

d. Pengaruh ROA Terhadap DPK Bank Umum Syariah

Dari hasil penelitian diperoleh bahwa ROA mempunyai pengaruh yang signifikan terhadap DPK Bank Umum Syariah dengan arah koefisien positif. Hal ini ditunjukkan dengan koefisien sebesar 47018.57 dengan tingkat signifikan 0,000 . Karena tingkat signifikan lebih kecil dari 0,05 maka secara parsial ROA berpengaruh secara signifikan dan positif terhadap Dana Pihak Ketiga. Hal ini berarti ROA merupakan salah satu ukuran kinerja keuangan yang dapat dijadikan sebagai dasar perhitungan seorang investor untuk menginvestasikan dananya pada Bank Syariah. Dengan melihat nilai ROA, maka investor akan dapat mengetahui apakah kinerja perbankan baik atau tidak. Melihat kondisi ini, maka dapat menguatkan pandangan masyarakat untuk menyimpan dananya di bank syariah, dan secara teoritis masyarakat dapat mempercayai kinerja bank, karena masyarakat dapat menyerahkan uangnya untuk dikelola oleh bank syariah yang berdampak pada peningkatan dana pihak ketiga. Selain itu, ROA dapat dijadikan sebagai bentuk perbandingan dalam memperoleh keuntungan melalui penyaluran dana kepada bank syariah dalam bentuk simpanan baik itu giro, tabungan, maupun deposit.

Penelitian ini juga didukung oleh penelitian yang dilakukan oleh Firdausi (2016) yang menyatakan bahwa Return On Assets (ROA) memiliki pengaruh yang signifikan dengan koefisien positif terhadap Dana Pihak Ketiga.

\section{KESIMPULAN}

Berdasarkan hasil penelitian yang telah dilakukan mengenai pengaruh Inflasi, Kurs, BI Rate, dan Return On Assets (ROA) terhadap Dana Pihak Ketiga (DPK) Bank Umum Syariah di Indonesia periode 2015-Juli 2019, maka dapat diambil beberapa kesimpulan antara lain:

a. Variabel Inflasi tidak berpengaruh signifikan dan positif terhadap Dana Pihak Ketiga (DPK) Bank Umum Syariah di Indonesia. Hal ini dikarenakan saat inflasi naik mengakibatkan daya beli masyarakat menurun. Namun hal ini tidak signifikan karena masyarakat masih bisa memenuhi kebutuhannya tanpa harus menarik dana yang ada dibank syariah untuk konsumsi melainkan melalui dana yang dimilikinya seperti menjual emas, asset, dan lain sebagainya.

b. Variabel Kurs berpengaruh signifikan dan positif terhadap Dana Pihak Ketiga (DPK) Bank Umum Syariah di Indonesia. Hal ini dikarenakan ketika dollar naik mengakibatkan dana pihak ketiga juga naik sehingga membuat masyarakat lebih memilih 
menyimpan uang di bank syariah dibandingkan untuk membelanjakannya.

c. Variabel BI Rate berpengaruh signifikan dan negative terhadap Dana Pihak Ketiga (DPK) Bank Umum Syariah di Indonesia. Artinya semakin tinggi tingkat suku bunga maka akan menurunkan dana pihak ketiga di bank syariah, hal ini disebabkan karena tingkat suku bunga yang tinggi akan memberikan keuntungan yang tinggi pula ke nasabah dan hal ini berakibat pada tingkat bagi hasil yang rendah.

d. Variabel Return On Assets (ROA) berpengaruh secara signifikan dan positif terhadap Dana Pihak Ketiga (DPK) Bank Umum Syariah di Indonesia. Artinya semakin tinggi ROA maka semakin tinggi pula Dana Pihak Ketiga. Hal ini sebabkan karena keuntungan dapatmenguatkan pandangan masyarakat dalam menyimpan dananya di bank dan masyarakat dapat mempercayai kinerja bank sehingga masyarakat dapat menyerahkan uangnya untuk dikelola oleh bank syariah.

\section{DAFTAR PUSTAKA}

Antonio, Muhammad Syafi'i. 2000. Bank Syariah Dari Teori ke Praktek. Jakarta: Gema Insani

Arif, M. Nur Rianto Al. 2014. Spin-off and its impact on the third party funds of Indonesian Islamic banking industry. Economic Journal of Emerging Markets, 6(1)

Arifin, Zainul. 2006. Dasa-Dasar Manajemen Perbankan Syariah. Jakarta: Pustaka Alvabet.

Atmadja, Adwin S. 1999. Inflasi di Indonesia: Sumber-Sumber Penyebab dan Pengendaliannya. Jurnal Akuntansi dan Keuangan, Volume 1

Badan Pusat Statistik. Laporan Publikasi Inflasi 20152019. www.bps.go.id diakses pada 21 Oktober 2019

Bank Indonesia. Laporan Publikasi BI Rate 20152019. www.bi.go.id diakses pada 23 Oktober 2019

Bank Indonesia. Laporan Publikasi Kurs/Nilai Tukar 2015-2019. www.bi.go.id diakses pada 22 Oktober 2019

Basuki, Agus Tri. 2017. Ekonometrika Dan Aplikasi Dalam Ekonomi, Edisi Pertama. Yogyakarta: Danisa Media

Danu, Pranata. 2013. Manajemen Perbankan Syariah. Jakarta: Salemba Empat
Dyatama, A. N. dan Yuliadi, I. 2015. Determinan Jumlah Pembiayaan Bank Syariah di Indonesia. Jurnal Ekonomi dan Studi Pembanguan. Volume 16, Nomor 1

Ferdiansyah. 2015. Pengaruh Rate Bagi Hasil dan BI Rate Terhadap Dana Pihak Ketiga Perbankan Syariah (Studi pada Bank Pemiayaan Rakyat Syariah yang Terdaftar di Bank Indonesia). Jurnal. Volume 2

Firdausi, I. 2016. Analisis Pengaruh Kinerja Perbankan Terhadap Dana Pihak Ketiga Bank Persero. Jurnal Keuangan dan Perbankan, Volume 20, Nomor 3

Fitri, Maltul. 2016. Peran Dana Pihak Ketiga Dalam Kinerja Lembaga Pembiayaan Syariah Dan Faktor-Faktor yang Mempengaruhinya. Jurnal. Volume VII

Ikatan Bankir Indonesia. 2014. Mengelola Kualitas Layanan Perbankan. Jakarta: PT Gramedia Pustaka Utama.

Kefi, Batista S. dan Sutono. 2013. Pengaruh Faktor Makro Ekonomi Terhadap Penghimpunan Dana Pada Bank Umum di Indonesia. Jurnal Ekonomi Manajemen Akuntansi. Halaman 9-10

Khoirunisa, Arrohmah. dan Soelistyo, A. 2010. Analisis Pengaruh Pendapatan Nasional dan Tingkat Suku Bunga Terhadap Penghimpunan Dana Pihak Ketiga pada Bank Umum di Indonsia. Jurnal Ekonomi Pembangunan, Volume 8 No. 1

Kurniawan. 2019. Analisis Data Menggunakan Stata Se 14 (Panduan Analisis, Langkah Lebih Cepat)

Lisa, Oyong. 2017. 'Analysis Macroeconomic On Islamicity Performance Index Through Fund Third Parties The Islamic Cooperation. International Journal of Social Science and Business. Volume 1

Mankiw, N, Gregory. 2006. Makro Ekonomi. Edisi 6. Terjemahan: Liza, Fitria, Nurmawan, Imam. Jakarta: Penerbit Erlangga. 2006.

Mishkin, Frederic S. 2008. Ekonomi Uang, Perbankan, dan Pasar Keuangan. Jakarta: Salemba Empat

Naomi, P. dan Dwijayanthy, F. 2009. Analisis Pengaruh Inflasi, BI Rate, dan Nilai Tukar Mata Uang terhadap Profitabilitas Bank Periode 20032007. Jurnal. Volume 3

Otoritas Jasa Keuangan. Statistik Perbankan Syariah 2015-2019. www.ojk.go.id. Di akses pada 24 Oktober 2019 
Pracoyo, Tri K. dan Pracoyo, Anita. 2004. Aspek Dasar Ekonomi Makro di Indonesia. Jakarta: Grasindo

Prasetya, B. Tan, Syamsurijal. dan Delis, A. 2015. Faktor-Faktor yang Mempengaruhi Penghimpunan Dana Pihak Ketiga Perbankan Syariah di Indonesia. Jurnal Perspektif Pembiayaan dan Pembangunan Daerah. Volume 3, Nomor 2

Prasetyoningrum, A Kristin. 2015. Analysis BI Rate and Return of Third Party Fund On Rate of Third PartyFund onIslamic Banking in Indonesia. Jurnal. Volume 2

Rianto, Nur. 2010. Teori Makro Ekonomi Islam. Bandung: Alfabeta

Rivai, Amalia. 2006. Identifikasi Faktor Penentu Keputusan Konsumen Dalam Memilih Jasa Perbankan: Bank Syariah vs Bank Konvensional.

Saekhu .2017. Dampak Indikator Makroekonomi terhadap Dana Pihak Ketiga Perbankan Syariah. Jurnal Ekonomi Islam. Volume 8, Nomor 1

Salvatore, D. 2004. Ekonomi Internasional, Edisi Kedua. Jakarta: Erlangga.

Sangadah, Dhurotus. 2013. Perilaku Dana Pihak Ketiga Dalam Merespon Perubahan Variabel Ekonomi Makro pada Bank Umum Swasta Nasional (BUSN) Provinsi Jawa Timur Periode 2000-2012. Jurnal Ekonomi Pembangunan. Volume 11 Nomor 2
Sopiana, Herli. 2012. Analisis Pengaruh Suku Bunga SBI Dan Inflasi Terhadap Penghimpunan Dana Pihak Ketiga (DPK) Perbankan di Indonesia. Jurnal Ekonomi Pembanguan, Volume 10, No. 1

Sugiono. 2014. Metode Penelitian Pendidikan Pendekatan Kuantitatif, Kualitatif, dan R dan D. Bandung: Alfabeta

Sukirno, Sadono. 2002. Pengantar Teori Makro Ekonomi, Edisi Kedua. Jakarta: PT. Grafindo Persada.

Usman, Rachmadi. 2009. Produk dan Akad Perbankan Syariah di Indonesia (Implementasi dan Aspek Hukum), Cetakan Pertama. Bandung: PT Citra Aditya Bakti

Wangsawidjaja, A. 2012. Pembiayaan Bank Syariah. Jakarta: PT Gramedia Pustaka Utama

Wibowo, Aldrin. dan Suhendra, Susi. 2010. Analisis Pengaruh Makro Ekonomi terhadap Dana Pihak Ketiga Bank Devisa di Indonesia. Universitas Sumatra Utara

Yuliadi, Imamudin. 2008. Ekonomi Moneter. Penerbit: Jakarta PT Indeks. 